Goldschmidt 2021 Abstract

https://doi.org/10.7185/gold2021.7571

\section{Dissolved gases monitoring to disclose regional hydrogeochemical interactions processes involved in mineral water genesis in non-active zone: the case of Corsica Island}

\author{
MARGAUX DUPUY ${ }^{1}$, EMILIE GAREL ${ }^{1}$, THIERRY \\ LABASQUE $^{2}$, DR. ELIOT CHATTON ${ }^{3}$, VIRGINIE \\ VERGNAUD $^{2}$, LUC AQUILINA ${ }^{2}$, SEBASTIEN SANTONI ${ }^{1}$, \\ ALEXANDRA MATTEI ${ }^{1}$ AND FRÉDÉRIC HUNEAU ${ }^{1}$ \\ ${ }^{1}$ Univ. of Corsica, CNRS, UMR 6134 \\ ${ }^{2}$ Univ. Rennes, CNRS, UMS 3343 \\ ${ }^{3}$ CNRS UMR6118
}

Presenting Author: dupuy_m@univ-corse.fr

In complex geological context, not seismically active, deep water-rock interactions associated with transit time and geological disparities can generate singular mineralisation associated to significant gaseous content. Widely used as tracers in seismically - and tectonically- active regions, the gaseous emission monitoring is underused to discriminate regional from local groundwater flow patterns. In this study the dissolved gas monitoring in groundwater has proven to be an innovative tool for reconstructing interactions involved in regional flows, and responsible for the genesis of highly diversified mineral watertypes.

The oriental plain of Corsica (France) has been investigated as an area with a wide variety of mineral waters (22 springs) emerging at the interface of magmatic, metamorphic and sedimentary rocks. Dissolved reactive $\left(\mathrm{N}_{2}, \mathrm{CO}_{2}, \mathrm{CH}_{4}, \mathrm{H}_{2} \mathrm{~S}, \mathrm{H}_{2}\right.$, $\mathrm{O}_{2}$ ) and noble gases $(\mathrm{Ne}, \mathrm{Ar}, \mathrm{He})$ on 9 springs have been quarterly sampled, and analysed by gas chromatography ( $\mu \mathrm{GC})$. The first results highlight 3 very contrasted gas abundances:

- $\mathrm{N}_{2}$-rich thermal waters $\left(54{ }^{\circ} \mathrm{C}\right)$, poorly mineralised, with noble gas occurrence as cortege gases, highlighting the influence of deep flow with a long groundwater residence time.

- $\mathrm{CO}_{2}$-rich cold waters $\left(<20{ }^{\circ} \mathrm{C}\right)$, low to highly mineralised, with $\mathrm{N}_{2}$ as cortege gase, highlighting the occurrence of deep flow interacting during upflow through metacarbonates.

- $\mathrm{CH}_{4}$-rich cold waters $\left(<20{ }^{\circ} \mathrm{C}\right)$, highly mineralised, with $\mathrm{H}_{2} \mathrm{~S}$ and $\mathrm{CO}_{2}$ as cortege gases, showing biotic anaerobic activity involvement in the gases composition of waters.

Then, based on the observed abundance of noble gases, theoretical recharge conditions were computed to defined recharge temperature, air- and He-excess. Computation results have stressed out the common origin of these three gas, depending on flow paths, reservoir conditions, biotic and abiotic interaction involvement. The circulation within magmatic reservoir is responsible for the deep $\mathrm{N}_{2}$-rich flow, which shows during his up-flow abiotic interactions with metamorphised carbonates rocks, increasing the $\mathrm{CO}_{2}$ content in water. Then under anoxic geological confinement in deep sedimentary layers, the $\mathrm{CO}_{2}$ is reduced into $\mathrm{CH}_{4}$ and $\mathrm{N}_{2}$ into $\mathrm{NH}_{4}$. In the shallowest sedimentary layers, the formed $\mathrm{CH}_{4}$ is degraded, due to the occurrence of rich-organic matter lithology, by biotic activity into $\mathrm{H}_{2} \mathrm{~S}$. 